\title{
DETERMINAN PEMILIHAN METODE KONTRASEPSI JANGKA PANJANG PADA AKSEPTOR KB AKTIF DI PUSKESMAS PEDAMARAN
}

\author{
Lusia Weni, ${ }^{1}$ M. Yuwono, ${ }^{2}$ Haerawati Idris ${ }^{3}$ \\ ${ }^{1}$ Bidang Kajian Umum Epidemiologi dan Biostatistik, Program Studi S2 Fakultas Kesehatan Masyarakat \\ Universitas Sriwijaya \\ ${ }^{2}$ Bagian Administrasi Kebijakan Kesehatan Fakultas Kesehatan Masyarakat Univeristas Sriwijaya \\ ${ }^{3}$ Bagian Biomedik Fakultas Kesehatan Masyarakat Univeristas Sriwijaya \\ Email : lusiaweni.heri@gmail.com
}

\begin{tabular}{|c|c|}
\hline $\begin{array}{c}\text { Track Record } \\
\text { Article } \\
\\
\text { Diterima : } 08 \text { Maret } 2019 \\
\text { Dipublikasi: } 25 \text { Juni } 2019\end{array}$ & 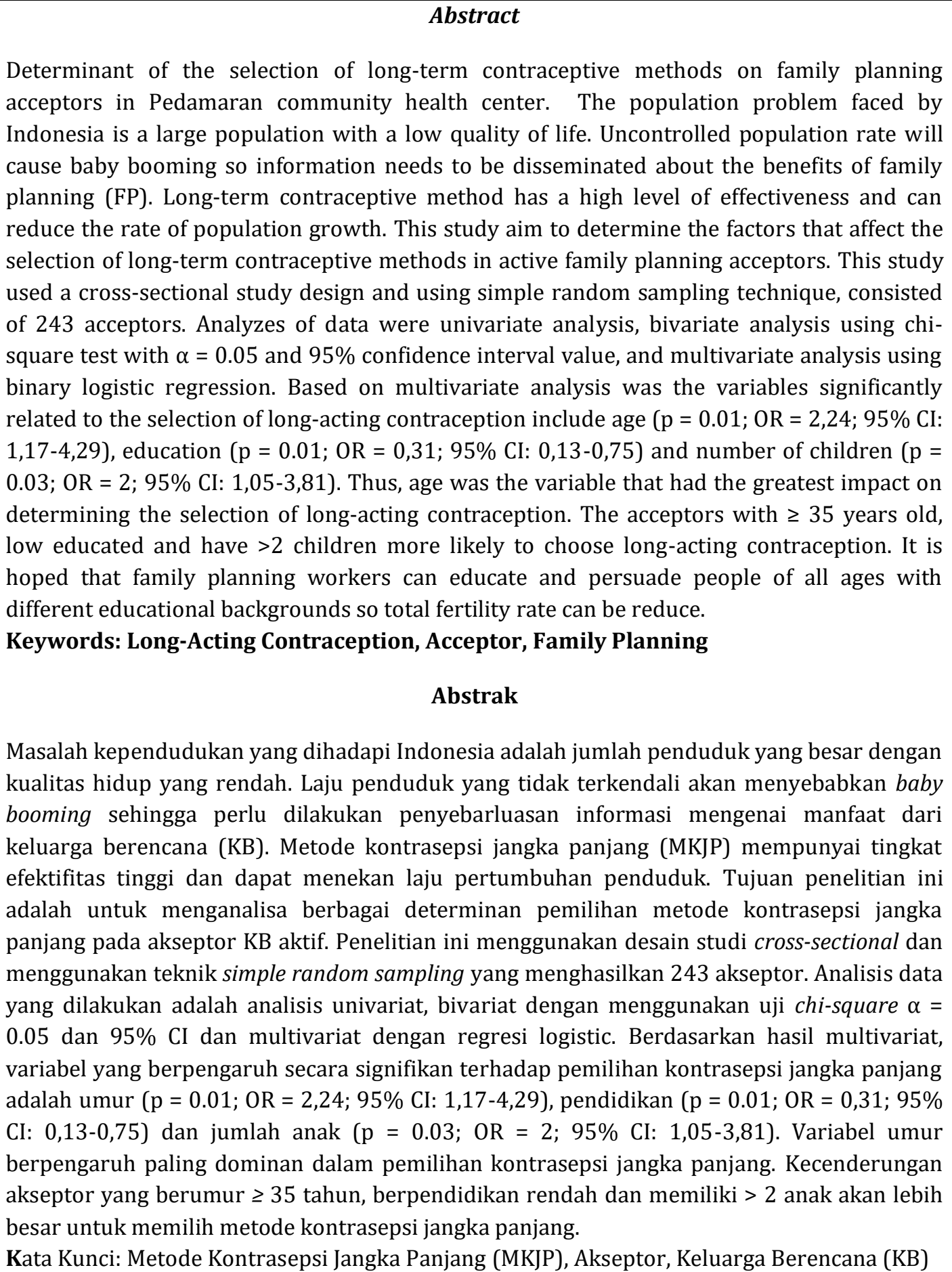 \\
\hline
\end{tabular}




\section{Pendahuluan}

Masalah kependudukan yang dihadapi Indonesia adalah jumlah penduduk yang besar dengan kualitas hidup yang rendah. Data dari Badan Pusat Statistik (BPS), jumlah penduduk Indonesia terus mengalami peningkatan. Pada tahun 2010 jumlah penduduk Indonesia sebesar 237.641.326 jiwa dan menjadi 255.461.700 jiwa pada tahun 2015. Jumlah penduduk ini akan semakin meningkat dari tahun ke tahun seiring dengan besarnya laju pertumbuhan penduduk yang diproyeksi sebesar 2,32 hingga tahun 2020 (BPS, 2017). Laju penduduk yang tidak terkendali akan menyebabkan baby booming sehingga perlu dilakukan penyebarluasan informasi mengenai manfaat dari keluarga berencana (KB) guna menumbuhkan kesadaran masyarakat untuk mengikuti progam KB. Program keluarga berencana sangat dibutuhkan untuk mencegah kehamilan yang tidak diinginkan dan untuk meningkatkan kesehatan serta kesejahteraan ibu dan anak. Metode kontrasepsi jangka panjang (MKJP) merupakan metode kontrasepsi mempunyai tingkat efektifitas tinggi. Metode ini antara lain implan, intra uterine device (IUD), metode operasi wanita (MOW) atau tubektomi dan metode operasi pria (MOP) atau vasektomi. Kecenderungan pasangan usia subur (PUS) untuk memilih metode non MKJP masih tinggi meskipun dengan potensi kegagalan kontrasepsi yang besar, baik dikarenakan penggunaan yang salah ataupun pemakaian yang tidak teratur dan efek samping yang membuat tidak nyaman. Data BPS Provinsi Sumatera Selatan tahun 2015 menunjukkan bahwa Kabupaten Ogan Komering Ilir (OKI) merupakan kabupaten yang memiliki jumlah penduduk terbesar ketiga di Sumatera Selatan dengan jumlah penduduk sebesar 787.513 jiwa dan tingkat laju pertumbuhan penduduk sebesar 1,45 persen. Pencapaian peserta KB Baru Kabupaten OKI tahun 2016 sebesar 23.136 akseptor dan hanya 3.905 (2,42\%) akseptor yang menggunakan MKJP. Jumlah akseptor tersebut belum memenuhi target yang ditetapkan oleh BKKBN Provinsi Sumatera Selatan yaitu sebesar 4.841 akseptor sehingga diperlukan suatu analisis determinan pemilihan MKJP pada akseptor KB Aktif. Tujuan penelitian ini adalah menganalisa berbagai determinan pemilihan metode kontrasepsi jangka panjang pada akseptor KB aktif.

\section{Metode}

Penelitian ini merupakan penelitian deskriptif observasional dengan menggunakan desain Cross Sectional. Populasi dalam penelitian ini adalah seluruh akseptor KB baik yang memakai kontrasepsi MKJP maupun non MKJP di Kecamatan Pedamaran hingga tahun 2016 yaitu sebanyak 7.224 akseptor Sampel dalam penelitian ini yaitu akseptor KB yang tercatat di wilayah kerja puskesmas Pedamaran dan praktik bidan mandiri yang melayani pelayanan kontrasepsi serta sampel harus memenuhi kriteria inklusi. Jumlah sampel minimal sebanyak 243 sampel dengan teknik pengambilan sampel menggunakan simple random sampling dengan cara undian. Variabel bebas pada penelitian ini adalah media, keamanan alat kontrasepsi, ketersediaan alat kontrasepsi, dukungan suami, kontak ke pelayanan, jaminan kesehatan, umur, pendidikan, jumlah anak, dan pendapatan sedangkan Variabel terikat pada penelitian ini adalah penggunaan metode kontrasepsi jangka panjang (MKJP) yaitu IUD, Implan, MOW dan MOP. Alur pengumpulan data yang digunakan dalam penelitian ini adalah data sekunder berupa identitas akseptor diurutkan dan pilih dengan cara undian hingga memenuhi jumlah minimal kemudian sampel yang terpilih dihubungi kemudian dilakukan wawancara di rumah responden. Data yang diperoleh dalam penelitian ini akan diolah melalui beberapa tahapan proses yaitu editing, coding, entry dan cleaning. Analis data yang akan dilakukan adalah analisis data univariat, bivariat dengan chi-square dan multivariat dengan regresi logistik. Penelitian ini dilaksanakan di Kecamatan Pedamaran pada bulan Agustus hingga Oktober 2017.

\section{Hasil}

Pada penelitian ini, ada 143 responden pengguna metode kontrasepsi non MKJP (58,8\%) dan 100 responden pengguna MKJP (41,2\%). Mayoritas responden menggunakan kontrasepsi suntik dengan jumlah 119 responden (49\%) dan metode kontrasepsi yang paling sedikit digunakan responden adalah kontrasepsi IUD dan MOP masing-masing berjumlah 1 responden (0,4\%) (Tabel 1).

Tabel 1. Penggunaan Metode Kontrasepsi

\begin{tabular}{clccc}
\hline No & & Metode & $\mathbf{n}$ & $\mathbf{\%}$ \\
\hline 1 & Pil & 22 & 9,1 \\
\hline 2 & Suntik & 119 & 49 \\
\hline 3 & Kondom & 2 & 0,8 \\
\hline 4 & IUD & 1 & 0,4 \\
\hline 5 & Implan & 89 & 36,6 \\
\hline 6 & MOW & & 9 & 3,7 \\
\hline 7 & MOP & Total & 1 & 0,4 \\
\hline
\end{tabular}


Tabel 2. Analisis Univariat Penggunaan MKJP Skala Numerik

\begin{tabular}{lcccccc}
\hline \multicolumn{1}{c}{ Variabel } & N & Mean & Median & SD & Min & Maks \\
\hline Umur (tahun) & 243 & 35,37 & 35 & 6,882 & 19 & 49 \\
\hline Pendapatan (Rupiah) & 243 & $2.683 .600,82$ & 2.000 .000 & $1.386 .402,197$ & 500.000 & 8.000 .000 \\
\hline Jumlah Anak (orang) & 243 & 2,68 & 2 & 1,25 & 1 & 9
\end{tabular}

Rata-rata umur responden yaitu 35,37 tahun dengan median 35 tahun. Responden termuda berusia 19 tahun dan tertua berusia 49 tahun. Rata-rata pendapatan responden sebesar Rp. 2.683.600,82 dengan pendapatan median sebesar Rp. 2.000.000. Pendapatan terendah responden yaitu Rp. 500.000 dan terbesar yaitu Rp. 8.000.000. Jumlah anak terbanyak yang dimiliki responden berjumlah 9 orang dan jumlah anak yang dimiliki responden paling sedikit 1 orang (Tabel 2).

Tabel 3. Analisis Univariat Penggunaan MKJP Skala Kategorik

\begin{tabular}{|c|c|c|}
\hline Variabel & $n=243$ & $\%$ \\
\hline \multicolumn{3}{|l|}{ Media } \\
\hline Media cetak & 221 & 90,9 \\
\hline Media elektronik & 22 & 9,1 \\
\hline \multicolumn{3}{|l|}{ Keamanan Alat Kontrasepsi } \\
\hline Tidak Aman & 43 & 17,7 \\
\hline Aman & 200 & 82,3 \\
\hline \multicolumn{3}{|l|}{ Ketersediaan Alat Kontrasepsi } \\
\hline Tidak & 71 & 29,2 \\
\hline Ya & 172 & 70,8 \\
\hline \multicolumn{3}{|l|}{ Dukungan Suami } \\
\hline Tidak Mendukung & 4 & 1,6 \\
\hline Mendukung & 239 & 98,4 \\
\hline \multicolumn{3}{|l|}{ Kontak dengan Petugas KB } \\
\hline Tidak pernah & 3 & 1,2 \\
\hline Pernah & 240 & 98,8 \\
\hline \multicolumn{3}{|l|}{ Jaminan Kesehatan } \\
\hline Tidak Menggunakan & 214 & 88,1 \\
\hline Menggunakan & 29 & 11,9 \\
\hline \multicolumn{3}{|l|}{ Umur } \\
\hline$<35$ Tahun & 107 & 44 \\
\hline$\geq 35$ Tahun & 136 & 56 \\
\hline \multicolumn{3}{|l|}{ Pendidikan } \\
\hline Rendah & 42 & 17,3 \\
\hline Tinggi & 201 & 82,7 \\
\hline \multicolumn{3}{|l|}{ Jumlah Anak } \\
\hline$\leq 2$ orang & 126 & 51,9 \\
\hline$>2$ orang & 117 & 48,1 \\
\hline \multicolumn{3}{|l|}{ Pendapatan } \\
\hline$<\mathrm{UMR}$ & 136 & 56 \\
\hline$\geq \mathrm{UMR}$ & 107 & 44 \\
\hline \multicolumn{3}{|l|}{ Tempat Pelayanan Kontrasepsi } \\
\hline Puskesmas & 30 & 12,3 \\
\hline Puskesmas Pembantu & 28 & 11,5 \\
\hline Bidan Praktik Swasta & 99 & 40,7 \\
\hline Rumah Sakit & 13 & 5,3 \\
\hline Lainnya & 73 & 30 \\
\hline
\end{tabular}

Pada tabel 3 diatas menunjukkan bahwa media yang paling sering digunakan oleh responden adalah media cetak yaitu sebanyak 221 responden (90,9\%). Faktor keamanan alat kontrasepsi dirasakan oleh 
responden dalam kategori aman sebanyak 200 responden (82,3\%). Variabel ketersediaan alat kontrasepsi MKJP terbanyak pada kategori ya dengan jawaban responden sebesar 172 (70,8\%) dan variabel dukungan suami terbanyak pada kategori mendukung yaitu sebanyak 239 responden $(98,4 \%)$. Kelompok kontak dengan petugas KB terbanyak pada kategori pernah yaitu sebesar 240 responden $(98,8 \%)$ sedangkan kelompok penggunaan jaminan kesehatan terbanyak pada kategori tidak menggunakan yaitu sejumlah 214 responden (88,1\%). Pada variabel umur terbanyak pada kelompok umur $\geq 35$ tahun yaitu sebesar 136 responden (56\%) dan kategori tingkat pendidikan terbanyak pada kategori tinggi yaitu sebanyak 201 responden (82,7\%). Untuk variabel jumlah anak terbanyak berada pada kategori $\geq 2$ orang dengan 117 responden (48,1\%) dan kelompok pendapatan terbanyak ada di kategori < UMR yaitu sebesar 136 responden (56\%). Sedangkan tempat pelayanan kontrasepsi yang menjadi pilihan utama responden adalah bidan praktik swasta dengan 99 responden $(40,7 \%)$.

Tabel 4. Analisis Bivariat Penggunaan MKJP

\begin{tabular}{|c|c|c|c|c|c|c|c|}
\hline \multirow{3}{*}{ Variabel } & \multicolumn{4}{|c|}{ Penggunaan MKJP } & \multirow{3}{*}{$\mathbf{N}$} & \multirow{3}{*}{$P$ value } & \multirow{3}{*}{$\begin{array}{c}\text { OR } \\
(95 \% \mathrm{CI})\end{array}$} \\
\hline & \multicolumn{2}{|c|}{ MKJP } & \multicolumn{2}{|c|}{ Non MKJP } & & & \\
\hline & $\mathbf{N}$ & $\%$ & $\mathbf{n}$ & $\%$ & & & \\
\hline Media & & & & & & \multirow{3}{*}{0,000} & \\
\hline Media cetak & 100 & 45,2 & 121 & 54,8 & 221 & & 0,55 \\
\hline Media elektronik & 0 & 0 & 22 & 100 & 22 & & $(0,48-0,61)$ \\
\hline \multicolumn{8}{|c|}{ Keamanan Alat Kontrasepsi } \\
\hline Aman & 100 & 50 & 100 & 50 & 200 & \multirow[t]{2}{*}{0,000} & 0,50 \\
\hline Tidak Aman & 0 & 0 & 43 & 100 & 43 & & $(0,43-0,57)$ \\
\hline \multicolumn{8}{|c|}{ Ketersediaan Alat Kontrasepsi } \\
\hline Ya & 72 & 41,9 & 100 & 58,1 & 172 & \multirow{2}{*}{0,775} & 1,11 \\
\hline Tidak & 28 & 39,4 & 43 & 60,6 & 71 & & $(0,63-1,94)$ \\
\hline \multicolumn{8}{|l|}{ Dukungan Suami } \\
\hline Mendukung & 100 & 41,8 & 139 & 58,2 & 239 & \multirow{2}{*}{0,146} & 0,58 \\
\hline Tidak Mendukung & 0 & 0 & 4 & 100 & 4 & & $(0,52-0,65)$ \\
\hline \multicolumn{8}{|c|}{ Kontak dengan Petugas KB } \\
\hline Pernah & 99 & 41,2 & 141 & 58,8 & 240 & \multirow[t]{2}{*}{1,00} & 1,40 \\
\hline Tidak Pernah & 1 & 33,3 & 2 & 66,7 & 3 & & $(0,13-15,7)$ \\
\hline \multicolumn{8}{|l|}{ Jaminan Kesehatan } \\
\hline Menggunakan & 6 & 20,7 & 23 & 79,3 & 29 & \multirow[t]{2}{*}{0,026} & 0,33 \\
\hline Tidak Menggunakan & 94 & 43.9 & 120 & 56,1 & 214 & & $(0,13-0,85)$ \\
\hline \multicolumn{8}{|l|}{ Umur } \\
\hline$\geq 35$ tahun & 70 & 51,5 & 66 & 48,5 & 136 & \multirow{2}{*}{0.000} & \\
\hline$<35$ tahun & 30 & 28 & 77 & 72 & 107 & & $(1,59-4,67)$ \\
\hline \multicolumn{8}{|l|}{ Pendidikan } \\
\hline Tinggi & 73 & 36,3 & 128 & 63,7 & 201 & \multirow{2}{*}{0.001} & 0,32 \\
\hline Rendah & 27 & 64,3 & 15 & 35,7 & 42 & & $(0,16-0,63)$ \\
\hline \multicolumn{8}{|l|}{ Jumlah Anak } \\
\hline$>2$ orang & 61 & 52,1 & 56 & 47,9 & 117 & \multirow[t]{2}{*}{0.001} & 2,43 \\
\hline$\leq 2$ orang & 39 & 31 & 87 & 69 & 126 & & $(1,44-4,10)$ \\
\hline \multicolumn{8}{|l|}{ Pendapatan } \\
\hline$\geq \mathrm{UMR}$ & 40 & 37,4 & 67 & 62,6 & 107 & \multirow[t]{2}{*}{0.297} & 0,75 \\
\hline$<\mathrm{UMR}$ & 60 & 44,1 & 76 & 55,9 & 136 & & $(0,45-1,27)$ \\
\hline
\end{tabular}

Pada tabel 4 di atas menunjukkan bahwa penggunaan MKJP terbanyak dipengaruhi oleh adanya media cetak yaitu sebesar 45,2\% Berdasarkan hasil uji statistik, didapatkan p value 0,000 yang berarti bahwa terdapat hubungan bermakna antara media dengan penggunaan MKJP. Pada variabel keamanan alat kontrasepsi, responden MKJP terbanyak menyatakan aman dalam penggunaan MKJP dengan nilai sebanyak 50\% dan tidak ada responden MKJP yang mengalami masalah keamanan alat kontrasepsi. Berdasarkan hasil uji statistik, didapatkan $p$ value 0,000 yang berarti bahwa terdapat hubungan bermakna antara keamanan alat kontrasepsi dengan penggunaan MKJP. Penggunaan MKJP pada variabel ketersediaan alat kontrasepsi MKJP terbanyak pada kategori ya yaitu sebesar 41,9\%. Berdasarkan hasil uji statistik, didapatkan p value 0,775 yang berarti bahwa tidak terdapat hubungan bermakna antara ketersediaan alat kontrasepsi dengan penggunaan MKJP.

Penggunaan MKJP pada variabel dukungan suami terbanyak pada kategori mendukung yaitu sebesar 41,8\%.Berdasarkan hasil uji statistik, didapatkan p value 0,146 yang berarti bahwa tidak terdapat hubungan bermakna antara dukungan suami dengan penggunaan MKJP. Penggunaan MKJP pada variabel kontak dengan petugas KB terbanyak pada kategori pernah yaitu sebesar 58,8\%. Berdasarkan hasil uji statistik, didapatkan p 
value 1,00 yang berarti bahwa tidak terdapat hubungan bermakna antara kontak dengan petugas KB dengan penggunaan MKJP. Penggunaan MKJP pada variabel jaminan kesehatan terbanyak pada kategori tidak menggunakan yaitu sebesar 43,9\%. Berdasarkan hasil uji statistik, didapatkan p value 0,026 yang berarti bahwa terdapat hubungan bermakna antara jaminan kesehatan dengan penggunaan MKJP. Penggunaan MKJP pada variabel umur terbanyak pada kategori $\geq 35$ tahun yaitu sebesar 51,5\%. Berdasarkan hasil uji statistik, didapatkan $p$ value 0,000 yang berarti bahwa terdapat hubungan bermakna antara umur dengan penggunaan MKJP.

Penggunaan MKJP pada variabel pendidikan terbanyak pada pendidikan rendah yaitu sebesar 64,3\%. Berdasarkan hasil uji statistik, didapatkan p value 0,001 yang berarti bahwa terdapat hubungan bermakna antara pendidikan dengan penggunaan MKJP. Penggunaan MKJP pada variabel jumlah anak terbanyak pada kategori $>2$ anak yaitu sebesar $52,1 \%$. Berdasarkan hasil uji statistik, didapatkan p value 0,001 yang berarti bahwa terdapat hubungan bermakna antara jumlah anak dengan penggunaan MKJP. Penggunaan MKJP pada variabel pendapatan terbanyak pada kategori <UMR yaitu sebesar 44,1\%. Berdasarkan hasil uji statistik, didapatkan p value 0,297 yang berarti bahwa tidak terdapat hubungan bermakna antara pendapatan dengan penggunaan MKJP.

Tabel 5. Model Akhir Regresi Logistik

\begin{tabular}{lcccc}
\hline \multicolumn{1}{c}{ Variabel } & B & Sig. & Exp(B) & $\mathbf{9 5 \%}$ CI \\
\hline Media Elektronik & $-20,64$ & 0,99 & 0,00 & 0,00 \\
\hline Alat Kontrasepsi Aman & 20,98 & 0,99 & 1,28 & 0,00 \\
\hline Umur $\geq 35$ Tahun & 0,81 & 0,01 & 2,24 & $1,17-4,29$ \\
\hline Menggunakan Jaminan Kesehatan & $-0,32$ & 0,58 & 0,72 & $0,23-2,27$ \\
\hline Pendidikan Tinggi & $-1,18$ & 0,01 & 0,31 & $0,13-0,75$ \\
\hline Jumlah Anak > 2 orang & 0,69 & 0,03 & 2,00 & $1,05-3,81$ \\
\hline Constant & $-20,63$ & 0,99 & 0,00 & \\
\hline
\end{tabular}

Tabel 5 menunjukkan hasil multivariat dan didapatkan tiga variabel yang memiliki nilai $p$ value $<0,05$ yaitu : umur, pendidikan dan jumlah anak. Variabel umur $\geq 35$ tahun memiliki nilai exp B sebesar 2,24 ( $p$ value 0,$01 ; 95 \%$ CI 1,17-4,29). Hal ini berarti bahwa kecenderungan orang dengan umur $\geq 35$ tahun untuk memilih MKJP 2,24 lebih besar daripada kecenderungan orang dengan umur $<35$ tahun. Variabel umur menjadi variabel yang paling dominan mempengaruhi pemilihan MKJP. Variabel pendidikan dengan nilai B sebesar yaitu 0,31 ( $p$ value 0,$01 ; 95 \%$ CI $0,13-0,75)$. Hal ini berarti bahwa kecenderungan orang yang menempuh pendidikan tinggi untuk memilih MKJP 0,31 kali dibandingkan dengan kemungkinan orang yang berpendidikan rendah. Variabel jumlah anak memiliki nilai exp B sebesar 2,00 ( $p$ value 0,03; 95\% CI 1,05-3,81). Hal ini berarti bahwa kecenderungan orang yang memiliki $>2$ anak untuk memilih MKJP 2 kali lebih besar dibandingkan dengan kecenderungan orang yang memiliki $\leq 2$ anak.

\section{Pembahasan}

Determinan penggunaan MKJP pada penelitian ini antara lain adalah media, keamanan alat kontrasepsi, jaminan kesehatan, umur, pendidikan dan jumlah anak. Dalam peraturan kepala BKKBN no. 165/PER/E1/2011 tentang pelayanan keluarga berencana metode kontrasepsi jangka panjang disebutkan bahwa tujuan KB MKJP adalah untuk meningkatkan kontak dan kualitas pelayanan KB MKJP bagi pasangan usia subur di semua tahapan keluarga.

Media memiliki hubungan bermakna dalam pemilihan MKJP walaupun pada analisis multivariat, variabel ini menjadi variabel perancu dengan nilai $p$ value sebesar 0,99. Penelitian Andhayani et al. (2011) menjelaskan bahwa penerimaan informasi tentang keluarga berencana berpengaruh signifikan terhadap pemilihan jenis kontrasepsi pada responden wanita usia 20-39 tahun. Sedangkan Speizer et al. (2014) mengatakan bahwa permintaan terhadap alat kontrasepsi modern yang terjadi sekarang ini sangat dipengaruhi oleh komunikasi diluar rumah, program radio lokal, slogan dan media cetak serta program televisi. Pemanfaatan media cetak dalam memberi informasi mengenai kontrasepsi dan keluarga berencana melalui spanduk, poster, leaflet, brosur yang dibagikan kepada masyarakat saat dilakukan pelayanan keliling oleh DPPKB Kab. OKI ataupun oleh petugas lini lapangan KB dapat meningkatkan pengetahuan masyarakat tentang berbagai metode kontrasepsi, keefektifannya dan efek samping yang dapat ditimbulkan oleh kontrasepsi serta berbagai informasi KB lainnya sehingga masyarakat dapat memilih metode kontrasepsi sesuai dengan kebutuhan dan keinginannya. 
Keamanan alat kontrasepsi memiliki hubungan bermakna dalam pemilihan MKJP walaupun pada analisis multivariat, variabel ini menjadi variabel perancu dengan nilai $p$ value sebesar 0,99. Penelitian ini sejalan dengan penelitian Rizali (2013) yang menyatakan bahwa ada hubungan antara keamanan alat kontrasepsi dengan pemilihan alat kontrasepsi suntik. Dijelaskan oleh Wilder et al. (2014) bahwa vasektomi dan sterilisasi (tubektomi) lebih aman dan lebih murah dibandingkan dengan sterilisasi tubal yang mempunyai resiko komplikasi dan lebih mahal. Penggunaan alat kontrasepsi oleh masyarakat dilandasi oleh aspek keamanan, keterjangkauan dan lama pemakaian tergantung dari masing-masing individu. Alat kontrasepsi MKJP dapat menurunkan angka Total Fertility Rate (TFR) dengan cepat, dapat dipakai dalam waktu lama, lebih aman dan efektif. Metode kontrasepsi jangka panjang mempunyai kelebihan pada keefektifannya dalam menunda kehamilan dengan jangka waktu pemakaian yang lebih lama, tidak mengganggu produksi ASI bagi ibu menyusui dan tidak mempengaruhi aktifitas seksual dengan efek samping yang lebih sedikit sehingga lebih aman untuk digunakan. Keunggulan MKJP ini perlu disosialisasikan kepada seluruh lapisan masyarakat sehingga masyarakat mengetahui dan berkeinginan menggunakan MKJP. Penyampaian informasi ini dapat dilakukan secara formal melalui penyuluhan ataupun secara informal dari penyuluh keluarga berencana.

Variabel ketersediaan alat kontrasepsi dan dukungan suami memiliki nilai $p$ value $>0,05$ yang artinya kedua variabel ini tidak memiliki hubungan yang bermakna dalam pemilihan MKJP. Pada penelitian Fienalia (2011) juga menyatakan bahwa dukungan suami tidak berpengaruh secara signifikan dengan penggunaan MKJP dan penelitian Kusumaningrum (2009) yang sama-sama menyebutkan bahwa dukungan pasangan tidak memiliki hubungan yang bermakna dengan pemilihan jenis kontrasepsi pada PUS. Pelayanan KB yang bermutu harus memenuhi beberapa syarat yaitu mampu memenuhi kebutuhan, tuntutan dan hak-hak responden. Mutu pelayanan KB ini paling tidak mencakup 6 aspek yaitu tersedianya berbagai pilihan metode kontrasepsi, tersedia informasi secara lengkap dan terbuka tentang pola pemakaian kontrasepsi, kemampuan teknis medis penyedia pelayanan KB sesuai dengan baku mutu pelayanan, interaksi petugas dengan responden berjalan baik, pelayanan yang diberikan disiapkan sehingga menunjang kelangsungan pemakaian kontrasepsi serta organisasi dan manajemen pelayanan berlangsung secara baik. Pria (suami) memiliki peran penting pada setiap tahap dalam proses reproduksi, sebagai mitra seksual dan memiliki pengaruh yang besar dalam tahap pengambilan keputusan di antara pasangan dan di dalam keluarga. Dukungan suami berpengaruh besar dalam pengambilan keputusan untuk menggunakan atau tidak dan metode apa yang digunakan. Bentuk dukungan yang diberikan kepada pasangan dapat berupa mengingatkan untuk kontrol, mengantar untuk mendapatkan pelayanan $\mathrm{KB}$, menyediakan dana serta memberikan persetujuan terhadap alat kontrasepsi yang digunakan pasangannya.

Penggunaan MKJP tidak berhubungan dengan kontak petugas karena memiliki $p$ value $>0,05$. Hasil ini didukung oleh penelitian Hadie dkk (2015) yang menyebutkan bahwa tidak ada hubungan petugas dalam pelayanan KB dengan penggunaan MKJP ( $p$ value 0,715). Hasil SDKI tahun 2012 menyebutkan bahwa 1 dari 7 wanita kawin yang tidak memakai kontrasepsi kontak dengan petugas kesehatan dan membahas KB. Wanita kawin yang tinggal di perkotaan dan tidak memakai kontrasepsi dibandingkan dengan wanita kawin di pedesaan. Kontak petugas kesehatan dalam upaya meningkatkan dan merubah sikap serta perilaku masyarakat terhadap KB MKJP dapat dilakukan dengan komunikasi, edukasi dan informasi (KIE) serta promosi kepada masyarakat melalui KIE massa, KIE kelompok ataupun komunikasi interpersonal/konseling.

Jaminan kesehatan memiliki hubungan bermakna dalam pemilihan MKJP walaupun pada analisis multivariat, variabel ini menjadi variabel perancu dengan nilai $p$ value sebesar 0,58. Arlian dan Yekti (2016) yang menyebutkan bahwa ada hubungan antara keikutsertaan jaminan kesehatan dengan penggunaan IUD Post Plasenta. Kontak terhadap pelayanan kesehatan akan semakin baik ketika individu dicakup dalam jaminan kesehatan. ${ }^{15}$ Winner et al (2012) menyatakan bahwa wanita yang tidak memiliki asuransi kesehatan akan cenderung memilih kontrasepsi suntik dibandingkan dengan metode kontrasepsi jangka panjang. Oesman (2017) yang menyebutkan bahwa pemanfaatan kartu BPJS untuk pelayanan KB masih sangat rendah yaitu 11,6 \% dengan kategori PBI maupun non PBI walaupun pemanfaatan BPJS oleh masyarakat berpeluang 3,8 kali lebih besar meningkatkan pemakaian MKJP dibandingkan yang tidak memakai BPJS. Umumnya responden MKJP mendapatkan pelayanan kontrasepsi secara langsung dari Dinas Pengendalian Penduduk dan Keluarga Berencana (DPPKB) Kab. OKI yang tidak dipungut biaya atau gratis sehingga memudahkan masyarakat untuk melakukan kontrasepsi terutama MKJP melalui kegiatan safari KB dan program KB Emas.

Umur memiliki memiliki nilai exp B sebesar 2,24 yang artinya bahwa kecenderungan orang dengan umur $\geq 35$ tahun untuk memilih MKJP 2,24 lebih besar daripada kecenderungan orang dengan umur $<35$ tahun. Hal ini sesuai dengan hasil penelitian Wijayanti dan Novianti (2017) yang menyebutkan 66,43\% pengguna MKJP dalam kategori umur 30-49 tahun. Sedangkan dalam penelitian Fienalia (2011) menyebutkan bahwa responden dengan umur $\geq 30$ tahun memiliki peluang sebesar 2,5 kali lebih besar untuk menggunakan MKJP dibandingkan dengan responden dengan umur $<30$ tahun. Penggunaan IUD, implan dan strelisasi wanita juga lebih tinggi pada kelompok umur 30-44 tahun dibandingkan dengan kelompok umur yang lebih muda. Laksmini (2012) menyatakan bahwa wanita yang berusia $\geq 35$ tahun akan memiliki peluang 2,1 kali lebih tinggi untuk menggunakan MKJP daripada wanita berusia < 35 tahun. Setiap peningkatan satu tahun usia perkawinan dapat meningkatkan penggunaan kontrasepsi sebesar 6\%. 
Pada hasil survei indikator kinerja program KKBPK RPJMN yang dilakukan oleh BKKBN juga terlihat bahwa pemakaian MKJP didominasi oleh wanita dengan umur $\geq 35$ tahun. Hal ini dipicu oleh keinginan untuk tidak memiliki anak lagi atau merasa anak yang dimiliki sudah cukup. Wanita yang berumur $\geq 35$ tahun juga berisiko untuk hamil dan melahirkan. Resiko yang dapat dialami antara lain penyakit diabetes gestasional dan penyakit hipertensi gestasional yang lebih mudah menyerang pada ibu hamil dengan umur diatas 35 tahun dikarenakan pengaruh hormon kehamilan. Kelahiran yang prematur dengan BB bayi lahir rendah serta kemungkinan melahirkan secara caesar juga lebih tinggi pada kelompok usia ini, serta besarnya kemungkinan terjadi ketidaknormalan kromosom pada bayi yang dilahirkan oleh ibu berusia diatas 35 tahun.

Pendidikan memiliki nilai B sebesar yaitu 0,31 yang artinya bahwa kecenderungan orang yang menempuh pendidikan tinggi untuk memilih MKJP 0,31 kali dibandingkan dengan kemungkinan orang yang berpendidikan rendah. Pada hasil survei indikator kinerja program KKBPK RPJMN juga menunjukkan hasil yang sama dengan hasil penelitian ini dimana penggunaan kontrasepsi secara umum menurun seiring dengan meningkatnya pendidikan seseorang. Metode kontrasepsi suntik 3 bulan, pil dan implant didominasi oleh akseptor dengan pendidikan SLTP ke bawah.

Orang dengan pendidikan rendah lebih mudah dibujuk dan dipengaruhi daripada orang yang berpendidikan tinggi apalagi ketika ada penyuluhan dan pelayanan gratis dari pemerintah daerah untuk masyarakat tanpa terkecuali. Hal ini memicu minat dan keingintahuan masyarakat terutama masyarakat dengan pendidikan rendah untuk datang dan melakukan pemasangan alat kontrasepsi.

Jumlah anak memiliki nilai exp B sebesar 2,00 yang berarti bahwa kecenderungan orang yang memiliki $>2$ anak untuk memilih MKJP 2 kali lebih besar dibandingkan dengan kecenderungan orang yang memiliki $\leq 2$ anak. Penelitian Fienalia (2011) juga menyebutkan bahwa responden yang mempunyai anak $\geq 3$ orang akan memiliki peluang 3,9 kali lebih besar untuk mengggunakan MKJP. Penelitian Putri dan Hari (2014) juga menyebutkan bahwa jumlah anak akan mempengaruhi responden dalam penggunaan MKJP. Hal ini senada dengan penelitian Sari (2016) yang menyatakan bahwa jumlah anak secara signifikan berpengaruh positif terhadap minat penggunaan MKJP.

Jumlah anak ideal yang ingin dimiliki oleh suatu keluarga dipengaruhi oleh umur dan pendidikan, dimana semakin tua umur wanita maka keinginan jumlah anak akan semakin besar begitupun sebaliknya sedangkan pendidikan wanita yang semakin tinggi akan menyebabkan keinginan anak idealnya semakin sedikit. Hasil survei demografi kesehatan Indonesia tahun 2012 juga menunjukkan bahwa banyak pria dan wanita di Indonesia memiliki anak lebih banyak dari yang mereka inginkan.

Semakin banyak jumlah anak tentunya semakin menyita perhatian lebih para orang tua. Pertimbangan ekonomi, kesehatan, biaya pendidikan turut mempengaruhi keputusan orang tua dalam menyikapi jumlah anak yang ingin dimiliki. Belum lagi kebutuhan primer seperti sandang, pangan dan papan yang mutlak harus dipenuhi sehingga semakin banyak jumlah anak yang dimiliki maka keinginan untuk menggunakan kontrasepsi MKJP semakin tinggi.

Pendapatan tidak memiliki hubungan yang bermakna dengan pemilihan MKJP. Hasil ini didukung oleh penelitian Fienalia (2011) yang menyatakan bahwa pendapatan tidak berhubungan secara signifikan dengan penggunaan MKJP karena memiliki nilai $p$ value 0,622. Penelitian Dehlendorf dkk (2010) juga menyebutkan bahwa keadaan sosial ekonomi tidak mempunyai efek yang signifikan pada masyarakat Latin $(p$ value $=0,93)$. Senada dengan hal tersebut, penelitian Agustini (2015) menghasilkan bahwa pendapatan tidak mempengaruhi permintaan KB maupun dengan kesesuaian penggunaan alat kontrasepsi. Pemerintah menyediakan secara gratis tiga jenis alat kontrasepsi di seluruh Indonesia yaitu Kondom, IUD/AKDR dan susuk KB/Implan sehingga masyarakat tidak perlu mengeluarkan biaya untuk mendapatkan pelayanan kontrasepsi yang ditanggung oleh pemerintah tersebut.

\section{Kesimpulan dan Saran}

Determinan pemilihan MKJP antara lain media, keamanan alat kontrasepsi, jaminan kesehatan, umur, pendidikan dan jumlah anak. Namun media, keamanan alat kontrasepsi dan jaminan kesehatan juga menjadi variabel perancu dalam penelitian ini. Hal yang paling dominan mempengaruhi pemilihan MKJP adalah umur, akseptor KB yang berumur $\geq 35$ tahun cenderung akan memilih MKJP sebesar 2,24 kali lebih besar daripada akseptor dengan umur $<35$ tahun. Sedangkan akseptor dengan pendidikan tinggi cenderung akan memilih MKJP 0,31 kali dibandingkan dengan kemungkinan akseptor yang berpendidikan rendah. Dan akseptor yang memiliki $>2$ anak cenderung memilih MKJP 2 kali lebih besar dibandingkan dengan akseptor yang memiliki $\leq 2$ anak.

Distribusi alat kontrasepsi IUD dan implan ke Rumah Sakit, puskesmas dan bidan praktik swasta secara merata, tepat waktu dan sesuai kebutuhan masyarakat. Target komunikasi, informasi dan edukasi (KIE) KB diperluas yaitu mengikutsertakan suami/pasangan dalam program penyuluhan di masyarakat. Lakukan penyuluhan dan sosialisasi kepada semua pasangan usia subur (PUS) baik yang pendidikan rendah maupun pendidikan tinggi, golongan umur $<35$ tahun maupun $\geq 35$ tahun dan dengan jumlah anak $\leq 2$ orang maupun $>2$ orang. 


\section{Daftar Pustaka}

Agustini, Ririn., Dwi Martiana \& Andrei Ramani. 2015. Kesesuaian Penggunaan Alat Kontrasepsi Berdasarkan Permintaan KB pada Pasangan Usia Subur (PUS) di Kecamatan Puger Kabupaten Jember. e-jurnal Pustaka Kesehatan. Vol. 3 No. 1

Andhayani, Annisa Rahma, Budi Palarto, Hari Penny Juliarti. 2011. Faktor-Faktor Yang Berhubungan Dengan Pemilihan Kontrasepsi Non IUD Pada Akseptor KB Wanita Usia 20-39 Tahun. Semarang : Universitas Diponegoro.

Arlian, Yekti Santriyandari. 2016. Hubungan Keikutsertaan Jaminan Kesehatan dengan Penggunaan IUD Post Plasenta di RSUD Wates Kulon Progo Yogyakarta Tahun 2016. Skripsi. Universitas 'Aisyiyah. Yogyakarta

Badan Kependudukan dan Keluarga Berencana Nasional. 2011. Pedoman Pelaksanaan Pelayanan KB Metode Kontrasepsi Jangka Panjang (MKJP). Jakarta : BKKBN.

Badan Kependudukan dan Keluarga Berencana Nasional. 2016. Laporan Kinerja Instansi Pemerintah 2015. Jakarta : BKKBN.

Badan Pusat Statistik. 2017. Proyeksi Penduduk Indonesia 2010-2035. Jakarta : BPS Indonesia.

Bakar, Sukawati Abu. 2014. Kesehatan Reproduksi dan Keluarga Berencana (Dalam Tanya Jawab). RajaGrafindo Persada. Jakarta.

Dehlendorf, Christine., Rachel Ruskin, Kevin Grumbach, Eric Vittinghoff, Kirsten Bibbins-Domingo, Dean Schillinger dan Jody Steinauer. 2010. Recommendations for Intrauterine Contraception : A Randomized Trial of the Effect of Patient's Race/Ethnicity and Socioeconomic Status. Am J Obstet Gynecol 203(4): 319

Dewi, PH Chandra dan Hari B Notobroto. 2014. Rendahnya Keikutsertaan Pengguna Metode Kontrasepsi Jangka Panjang Pada Pasangan Usia Subur Jurnal Biometrika dan Kependudukan, Vol. 3, No. 1 Juli 2014: 66-72

Fienalia, Rainy Alus. 2011. Faktor-faktor yang Berhubungan dengan Penggunaan Metode Kontrasepsi Jangka Panjang di Wilayah Kerja Puskesmas Pancoran Mas Kota Depok Tahun 2011. Skripsi.

Ghimire, Dirgha J. \& William G. Axinn. 2013. Marital Processes, Arranged Marriage, and Contraception to Limit Fertility. Springer. 1663-1686

Hadie Djauharoh A, Martha Irene Kartasurya \& Cahya Tri Purnami. 2015. Beberapa Faktor yang Berhubungan dengan Penggunaan Metode Kontrasepsi Jangka Panjang (Studi pada Akseptor KB di Kabupaten Sidoarjo Provinsi Jawa Timur). Jurnal Manajemen Kesehatan Indonesia. Vol.3 No.1

Hartanto, H. 2002. Kamus Kedokteran Dorland Ed.29. Jakarta : EGC Rizali, Muhammad Irwan., Muhammad Ihsan \& Ummu Salmah. 2013. Faktor yang Berhubungan dengan Pemilihan Metode Kontrasepsi Suntik di Kelurahan Mattoangin Kecamatan Mariso Kota Makassar. Vol. 9 No. 3 : 176-183, Jurnal MKMI.

Kusumaningrum, Radita. 2009. Faktor-faktor yang Mempengaruhi Pemilihan Jenis Kontrasepsi yang Digunakan Pada Pasangan Usia Subur. Skripsi. Universitas Diponegoro. Semarang.

Laksmini, Puji. 2017. Faktor-faktor yang Berhubungan dengan Penggunaan Metode Kontrasepsi Jangka Panjang (MKJP) di Pulau Jawa. http://www.researchgate.net/publication.html.

Mappaware, Nasrudin Andi. 2016. Pemilihan Metode Kontrasepsi Jangka Panjang. http://www.alumnifkumi.org/artikel.html. Di unduh 010818

Maryani, Sri., Ulty Desmarnita \& Sri Djuwutaningsih. 2013. Dukungan Suami dalam Pemilihan Metode Kontrasepsi Jangka Panjang. Jurnal Keperawatan Vol. 1 No. 1 Hal 49-56.

Memmi, Sarah dan Annabel Desgress Du Lou. 2015. Gender Relations and Contraceptive Practices of Palestinian Cuoples. Population Journal. Vol. 70 No. 2 ; 273-308

Oesman, Hadriah. 2017. Pola Pemakaian Kontrasepsi dan Pemanfaatan Kartu Badan Penyelenggara Jaminan Sosial (BPJS) Kesehatan dalam Pelayanan Keluarga Berencana di Indonesia. Jurnal Kesehatan Reproduksi Vol. 8 No.1 Hal 15-29

Sari, Eminur Itri. 2016. Faktor-faktor yang Berhubungan dengan Rendahnya Minat Ibu Terhadap Penggunaan Metode Kontrasepsi Jangka Panjang di BPS Sri Romdhati Semin Gunung Kidul. Naskah Publikasi. Fakultas Ilmu Kesehatan, Universitas 'Aisyiyah Yogyakarta.

SDKI. 2012. Survei Demografi dan Kesehatan Indonesia. Jakarta.

Speizer, Ilene S., Megan Corron, Lisa Calhoun, Peter Lance, Livia Montana, Priya Nanda, et al. 2014. Demand generation activities and modern contraceptive use in urban areas of four countries: a longitudinal evaluation. Global Health: Science and Practice. Vol.2, No. 4.

Wijayanti, RU \& Novianti. 2017. Penggunaan Metode Kontrasepsi Jangka Panjang (MKJP) di Wilayah Kerja Puskesmas Kecamatan Sawah Besar Jakarta Pusat. Jurnal Ilmiah Widya Vol.4 No.1

Wilder, Venis., Georgia Bromfield., Gabrielle deFiebre., Linda Prine. 2014. Disparities in Contraceptive Care. Journal of Health Care for the Poor and Underserved 25 (2014): 451-459.

Winner, Brooke., Jeffrey F. Peipert., Qiuhong Zhao., Christina Buckel et al. 2012. Effectiveness of Long-Acting Reversible Contraception The New England Journal of Medicine 366(21) :1998-2007. 